Canadian University Music Review

Canadian University Music Review

Revue de musique des universités canadiennes

Ralph P. Locke and Cyrilla Barr, eds. Cultivating Music in

America: Women Patrons and Activists since 1860. Berkeley

and Los Angeles: University of California Press, 1997. xi, 357 pp.

ISBN 0-520-083-954 (hardcover)

Mona Mender. Extraordinary Women in Support of Music.

Lanham, Md., and London: Scarecrow Press, 1997. x, 309 pp.

ISBN 0-8108-3278-X (hardcover)

\title{
Caryl Clark
}

Volume 20, numéro 2, 2000

URI : https://id.erudit.org/iderudit/1014471ar

DOI : https://doi.org/10.7202/1014471ar

Aller au sommaire du numéro

Éditeur(s)

Canadian University Music Society / Société de musique des universités

canadiennes

ISSN

0710-0353 (imprimé)

2291-2436 (numérique)

Découvrir la revue

Citer ce compte rendu

Clark, C. (2000). Compte rendu de [Ralph P. Locke and Cyrilla Barr, eds. Cultivating Music in America: Women Patrons and Activists since 1860. Berkeley and Los Angeles: University of California Press, 1997. xi, 357 pp. ISBN

0-520-083-954 (hardcover) / Mona Mender. Extraordinary Women in Support of

Music. Lanham, Md., and London: Scarecrow Press, 1997. x, 309 pp. ISBN 0-8108-3278-X (hardcover)]. Canadian University Music Review / Revue de musique des universités canadiennes, 20(2), 148-151.

https://doi.org/10.7202/1014471ar

All Rights Reserved (C Canadian University Music Society / Société de musique des universités canadiennes, 2000
Ce document est protégé par la loi sur le droit d'auteur. L’utilisation des services d'Érudit (y compris la reproduction) est assujettie à sa politique d'utilisation que vous pouvez consulter en ligne.

https://apropos.erudit.org/fr/usagers/politique-dutilisation/ 
Ralph P. Locke and Cyrilla Barr, eds. Cultivating Music in America: Women Patrons and Activists since 1860. Berkeley and Los Angeles: University of California Press, 1997. xi, 357 pp. ISBN 0-520-083-954 (hardcover).

Mona Mender. Extraordinary Women in Support of Music. Lanham, Md., and London: Scarecrow Press, 1997. x, 309 pp. ISBN 0-8108-3278-X (hardcover).

Cultivation. Allusions and associations for this word abound. To cultivate is to prepare for growth, to till, foster, further, refine, and encourage. Thus the latent power lying dormant in the image of a seed being planted, nurtured, and harvested, while not exclusively within the domain of the female, nevertheless invokes the power and potential inherent in the feminine. Cultivation's engagement with fertility, growth, and new life forms the germinating kernel of the essays contained in Cultivating Music in America and the activities of the enterprising women eloquently recorded therein.

The joint editors, Ralph Locke and Cyrilla Barr, each of whom have contributed individual chapters to this volume, are to be congratulated for the wonderful set of essays gathered here. Locke and Barr, who have each published articles on related subjects before (he in 19th-Century Music and she in the Journal of Musicology, both in 1993), now join together to create a truly powerful book. They also manage to bring coherence to a potentially disparate collection of essays by several different authors while permitting extended individual evaluations of the four main subjects: the Bostonian art collector Isabella Stewart Gardiner; Jeanette Thurber, who brought Antonín Dvořák to New York as head of the National Conservatory; the pianist, composer, and patron Elizabeth Sprague Coolidge who commissioned works from several important composers including Bartók, Copland, and Stravinsky; and Sophie Drinker, whose Women and Music: The Story of Women in Their Relation to Music, published in 1948 , represents a musicological milestone. The work of these four enterprising women, presented roughly chronologically, are further elucidated through documentary vignettes (letters, diaries, newspaper reports, etc.) scattered throughout the text which allow the lost voices of relevant individuals to be heard, unmediated. Additional chapters discuss other musical activists of lesser renown, describe relevant trends-including the institution of musical clubs and other kinds of organizations in various locales-and provide further contextual information, permitting a more complete survey of the activities of women in musical America in the late nineteenth and early twentieth centuries.

The introductory chapter, "Music Patronage as a "Female-Centered Cultural Process," embeds the customary summary of forthcoming chapters within a lively and thought-provoking discussion of the broader sociological issues and challenges to conventional musicology raised by the topic of women and patronage. Because male composers and the now canonic musical masterpieces they created have dominated traditional musicology, "the different ways in which other members of the social body-the professional or amateur performer, the patron, the music educator, the critic, the audience member or compact disk purchaser-experience and influence music," is rarely considered. "All these 
individuals play essential roles in the musical life of a given place and time, enabling as they do the creation-and the continued meaningful existence, in performance and interpretation -of those great musical works that we are taught to admire and love" (p.3). Social feminism and political and ideological developments are inevitably at the core of the collection, although some authors seem more comfortable than others with the large and looming questions these positions pose (more on this later).

The role of selected women patrons and the importance of unremunerated work and volunteer efforts in the development of American musical culture forms the core of the individual essays. In the words of the editors, "a few varied stories ... must 'stand for' a sturdy structural cord in the tapestry of American music history" (pp. 9-10). The essays attempt to correct the imbalance or redress the "distortion of omission" of women patrons, both those of the middle and upper classes as well as those of lesser means who created institutional structures in which music might thrive. Although a book devoted to the role of the "patroness" may rest uncomfortably with certain current feminist ideals, since it appears to exonerate women for acquiescing to the very patriarchal system which has deprived them of public recognition and financial and professional parity with their male counterparts, the women whose efforts are here lauded have too long been overlooked precisely because of their gender and the perception of their endeavours as "women's work." Validated here are the experiences of women as volunteers, a troubling position in the wake of the women's movement since such work is perceived as undercutting the position of those doing paid work and thus in collusion with the problem being fought. Nevertheless volunteerism, work that is done without legal or financial benefits, has made a vibrant contribution to the social fabric of music making and has worked to change the very nature of philanthropy in America. In some sectors, women patrons have helped to erode resistance to American music.

Chapter 1 provides the contextual background for the forthcoming chapters. Here America's musical institutions and foundations, established and furthered by its libraries, schools, conservatories, orchestras and other performing groups, publishing industry, and native and immigrant communities, are surveyed with special attention paid to the role of individual women, groups, and organizations. This sets up Linda Whitesitt's chapter on "Women as 'Keepers of Culture," and the role of the "clubwoman movement" in nurturing cultural and educational life in various locales. Many women who served as keepers, not makers, of culture, are here given an identity and recognized for their invaluable contributions, although their efforts "simultaneously perpetuated a cultural hierarchy that excluded the women themselves" (p. 81). Following the chapters on Gardiner (Locke) and Thurber (Emanuel Rabin) is Joseph Horowitz's essay on Laura Langford, who, as head of the Seidl Society, first brought Wagner's music to Brooklyn. His research is reminiscent of Carl Morey's work on Wagner in Toronto (Canadian University Music Review, no. 18/2 [1998]: 25-37). In between the chapters on Coolidge (by Barr) and Drinker (by Ruth Solie) are two welcome mediating essays, the first of which bolsters the argument articulated by Barr about the powerful role played by several astute women 
in furthering modernist American music in New York between the wars (by Carol Oja) and the second devoted to black women activists whose endeavours "responded to the distinct needs and tapped the resources (e.g., the churches) of the African-American community" (by Doris Evans McGinty). Unproblematized here are the issues of race and segregation, despite the precedent set (not to invoke stereotypes) by recent jazz studies.

Of these chapters, only the one by Ruth Solie seems particularly at ease with the larger feminist issues and critical apparatus articulated at the volume's outset. Solie's subject becomes more than a historical subject; indeed, Drinker's class and position of privilege are not only exposed and dealt with in "Culture Feminism and the Sacred" (chapter 9), but also form the basis of a broader polemic. True, Solie has visited the subject of Sophie Drinker's Music and Women before, most notably in Disciplining Music: Musicology and Its Canons (1992), and this long acquaintance and seeming discomfort with her subject, and probably her own tempered idealism, enable her to establish a reflective distance. The ambivalences she raises about the Drinker legacy prompt one to wish that other contributors to the volume might have applied more rigorous critical apparatus or exercised greater political savvy. For instance, the questions Solie raises about the "curious contradictions that seem rooted in the cultural psyche of Americans [in the early part of this century] and of which the ambiguities in the Drinkers' philosophy are only symptomatic" (p. 275). How, for example, could one "justify and promote an elite high-culture art form, as against vernacular manifestations, in a country whose official ideology was [is?] egalitarian?" (p. 275). While perhaps less problematic in other chapters, such questions are never addressed by their authors. Only Ralph Locke in his "straight-fromthe-hip" concluding chapter, much of which has appeared in print before (see note of pp. 324-25), tackles larger theoretical issues. One wonders when it will be acceptable to expose tensions, such as the sacralization of art that shaped Sophie Drinker's scholarship, in the work of others.

All of these essays, most notably those by Locke, are copiously footnoted and annotated-sometimes to a fault. Are these numerous annotations and digressions meant to counterbalance the possible criticisms from some sectors about the worthiness of the subject or the scholarly credentials established within the field? If the extended annotations are in any way responsible for the unusually small print used in both the main text and in the notes, then the tendency towards overdocumentation might be criticized; abnormal eye strain is the most immediate effect, which is definitely not the norm for books published by the University of California Press. I would rather conclude that the small typeface allowed for the inclusion of a larger number of submissions, with the concomitant reward that more voices, including authors and subjects, are heard.

Parallel acts of cultivation in the Canadian context are difficult to draw. Since we have adopted a more European model of government-based support for the arts, Canada has produced fewer musical philanthropists and comparatively few women patrons. Our many "cultivators" deserve better recognition, however, as do the grassroots efforts of the countless individuals who have nurtured performance, pedagogy, production, and consumption of music across this 
nation. Work on musical institutions is underway, a noteworthy example being Robin Elliot's admirable 1997 historical account Counterpoint to a City: The First One Hundred Years of the Women's Musical Club in Toronto (similar ones could be written for comparable groups in other centres-Montreal or Winnipeg, for example-where musical philanthropy has flourished through women working in groups). Histories that also explore individual identities and the interactive dynamics of musico-cultural environments in large and small communities, inside and outside the Western classical music tradition, potentially have much to offer. The vibrant decision-making processes of so many individuals and organizations await unearthing in our rich and eclectic Canadian musical heritage, and this need not necessarily be women's work.

***

The second book under review, Extraordinary Women in Support of Music, reaps few rewards for the reader. It opens inauspiciously and rarely rises above its mediocre aims. In her preface Mona Mender explains that, owing to her experience of serving on the board of trustees of the New Jersey Symphony Orchestra and participating in the American Symphony Orchestra League, she was struck by the high number of women who were engaged in fundraising for the symphony and its programs and of the countless other women who were contributing enormous amounts of time, energy and money to symphony organizations throughout America. But rather than documenting this involvement or attempting to explore the full range of activities undertaken by women as volunteers, professionals, and administrators in today's symphonic organizations and assessing their impact, an endeavour which would have given a much-needed voice to this silent underclass of symphonic workers, Mender has embarked on a much less noble project - that of producing a very personal and idiosyncratic who's who of historical women involved in furthering the musical arts throughout the ages. By choosing this time-honoured celebratory route, Mender may have sought to pay tribute to the "fascinating and diverse women in the Western world who have done us all a great service by furthering music and helping musicians" (p. x). In the end, however, her project, devoid of scholarly rigour, methodology, and perspective, offers little to those striving to introduce or reposition the study of women and music in academia. How much more worthwhile the author's efforts would have been if the many issues engaged by the contributors to Cultivating Music had been explored from a different or complementary perspective. Unfortunately, Extraordinary Women is anything but, leaving one to muse about "uncultivated" opportunities ... and the prospect of another rejuvenating spring. 